\title{
SUSTAINABLE INTENSIFICATION IN AGRICULTURE AS A FACTOR OF ACHIEVING FOOD SECURITY
}

\author{
Katarina Đurićc ${ }^{1}$ Zoran Njegovan ${ }^{2}$
}

\begin{abstract}
Summary
Ending hunger, achieving food security and promoting sustainable development are at the top of the list of United Nations sustainable global development priorities after 2015. In addition to many positive effects, efforts of mankind regarding the reduction of rural poverty realized through the Green Revolution have had many negative effects, primarily related to natural resources. Irreversible devastation of land, air and water quality deterioration and jeopardizing biodiversity have been recognized as key elements of unsustainability of existing agricultural development concept. Consequently, there is a need for the adoption of a new concept of agricultural development, which will lie between intensive conventional and organic farming.

The concept which has already been applied in some regions of the world and whose basic goal is to find a way to increase production with a negligible negative impact on the environment is sustainable agricultural intensification. The aim of this paper is to look at both positive and negative aspects of biotechnology development so far and point out the place and role the sustainable intensification concept should have in relation to conservation of natural resources and achievement of food security.
\end{abstract}

Key words: food security, biodiversity, land, green revolution, sustainable intensification

JEL: $Q 15, Q 18$

\section{Introduction}

Food security is high on the list of global development priorities. As a result of the global population growth, there is an increase in food demand, competition for the use of land, water, energy and other agricultural inputs. Climate changes present another challenge for agriculture, especially in developing countries which are faced with food insecurity.

1 Katarina Đurić, Ph.D., Associate Professor, University of Novi Sad, Faculty of Agriculture, Dositeja Obradovića Square no. 8, 21000 Novi Sad, Serbia, Phone: +381 214852 232, E-mail: katarina.djuric@polj.uns.ac.rs

2 Zoran Njegovan, Ph.D., Full Professor, University of Novi Sad, Faculty of Agriculture, Dositeja Obradovića Square no. 8, 21000 Novi Sad, Serbia, Phone: +381 214853 393, E-mail: njegovan@polj.uns.ac.rs

EP 2016 (63) 3 (929-942) 
According to the global development not only the regions affected by food crisis should confront this problem. Namely, the problem of one region spreads very quickly raising both economic and political issues around the world.

The resolution to this problem requires finding new solutions in the field of food production that is, in the so-called food system. One of the solutions, supported by certain countries and international institutions, is the concept of "sustainable intensification". Taking into account limitations of farmland, the goal of sustainable intensification is to increase food production from existing available farmland while minimizing the pressure on the soil and without jeopardizing food production capacities in the future. Although the concept of sustainable agricultural intensification has been accepted by a certain number of countries, it came under strong criticism, both for its sole focus on production and for certain controversies associated with it.

\section{Research Method and Objectives}

Having in mind the subject and aim of the research, qualitative research methods common for social sciences have been used in this research. Descriptive and historical analysis has been mostly applied in the paper. These methods are based on studying impact of biotechnology achievements on the food and environmental circumstances. Comparative analysis has also been used to a great extent, since it is necessary to review and compare positive and negative impacts on implementation of biotechnology achievements on the conservation of natural resources and biodiversity, on one side and food security, on the other.

The aim of the research is to analyze the possibility for the concept of sustainable intensification of agriculture to influence the decrease of rural poverty in developing countries and improvement of the world food situation. The significance of this concept in present and future developing agendas, both on national and global level is assessed by reviewing the scope and aspect of sustainable agricultural intensification.

\section{Current food situation}

In the year 2000, the United Nations adopted a document called "The Millennium Declaration" which defined eight millennium development goals. The first goal is optimistically defined as "eradication of extreme poverty and hunger by 2015". Three more realistic sub-goals are defined within this general goal:

- Halve the proportion of people who live in the extreme poverty and whose income and/or consumption is less than USD 1 per day,

- Achieve full and productive employment for all working age population, especially women and young people, and

- Halve the proportion of undernourished people compared to 1990. (www.un.org/ millenniumgoals/). 
Regardless of numerous limitations embodied in unfavourable, both climate and economic conditions, certain countries have managed to achieve significant improvements related to the realization of the millennium goal. According to official UN data, the sub-goal 1 was realized during 2010. That year, as compared to 1990, the number of the poor was reduced by around 700 million. Owing to commitment of Governments of certain countries, as well as active support of relevant international institutions and organizations, certain results were achieved in the second and third sub-goal. However, despite these developments, the number of undernourished population in the world remains unacceptably high. Namely, on the global level, in 2014 there were still 1.2 billion people living in extreme poverty; out of this number, 842 million people, 99 million of who are children up to 5 years of age, cannot meet basic nutritional needs (UN, 2014).

In order to reach as realistic conclusions as possible, the world food state should be observed not only from the aspect of the number of undernourished people, but also from the aspect of food quality. Looking at the latter, it can be noticed that available calories per capita has increased, but the intake of microelements still falls behind as compared to the realistic needs. Owing to the Green Revolution, whose idea was to reduce poverty and hunger in the world, the production and availability of food has increased in some developing countries. It is because of the Green Revolution that in the period between 1960 and 1990 the participation of undernourished people in the total world population significantly decreased (Đurić, 2015). Improvements made regarding the food availability, which was the result of price drops, contributed to the increase of energy intake in the nutrition of the poor. For example: the drop in the price of rice in Bangladesh made it possible for people to spend money on other sorts of food (UN, 2013). However, positive effects of the Green Revolution on the quality of nutrition of the population are not equal in all regions and countries. Although, due to the growth of yield and productivity in the agricultural production, the consumption by the number of calories per capita per day increased, the majority of the poor have not seen the improvements in the quality of food, measured by the intake of the most important microelements. As a result, despite the growth in the calorie intake, the problem of malnutrition is still present in many countries.

One of the factors which greatly determines the world food state is the population trend. The current world population is 7.2 billion. The United Nations projections anticipate that the world population will increase by more than a billion people over the next 12 years, thus reaching the figure of 9.6 billion people by 2050 (UN, 2013). Moreover, the projections estimate that the most dynamic growth is to be expected in countries most vulnerable to food security. Namely, more than a half of the anticipated population growth will be on the African continent.

Traditionally, the population in developed countries has a significantly slower growth trend compared to developing countries. According to the "World Population Prospects" report, the population of developed countries is expected to grow slowly from now until 2050. In contrast, 49 developing countries are projected to double in size from around 900 million in 2013 to 1.8 billion in 2050 . 
The report also states that India is expected to become the world's largest country, passing China, when both countries will have population of 1.45 billion by 2028 . After that, it is expected that India's population will continue to grow, while China's is expected to start decreasing. Furthermore, according to the UN projections, Nigeria's population is expected to surpass that of the United States by 2050.

In contrast to developing countries, Europe is facing growing aging population. Namely, Europe's population is projected to decline by $14 \%$ by 2050 . Similarly to the situation in previous decades, the most dynamic population growth is projected and expected in regions most vulnerable to food security.

The expected growth of the world population, together with the intention to eradicate hunger and poverty in the most jeopardized regions of the world, prove the need for the global growth of agricultural production. However, increasing pressure on the environment, seen through growing land degradation, pollution of water resources, more prominent climate change and other adverse effects, are the reasons why agricultural production should be based solely on a sustainability principle. Therefore, the sustainable development concept should become a new philosophy of development, including not only economic, but also, moral, social and health aspects (Pejanović, 2015).

Production growth and yield increase should be some of the responses to a growing demand, but not the only ones (Goldfray, Garnett, 2014). Following the sustainability principle, in addition to the yield increase, it is important to achieve the following:

- $\quad$ change the model of demand in terms of demand growth for so-called: resourceintensive food produces such as meat and dairy products,

- rationality in the consumption in terms of food waste reduction,

- establish the measures of food (agrarian) policy which would facilitate the improvement of food system efficiency and ensure availability of food for everyone (Tilman et al., 2011).

Nonetheless, it is unlikely that there is any other solution, apart from the increase in yield and production, which could solve the problem of food insecurity in the world. The increase in yield is the key factor for elimination of hunger and poverty, especially from the aspect of developing countries. Nowadays, the increase in yield is a number one requirement in almost all low-income countries. However, in the long-run, temporary growth of yield and production should not be the main goal, but creating conditions for continuous improvement of production potentials in order to meet food demand in the future. Furthermore, every option offered as a solution should be environmentally acceptable, that is, sustainable.

\section{Green revolution - advantages and limitations}

Although the Green Revolution, as an attempt to reduce hunger and poverty in the world, was put into practice during the 1950s, extensive research whose goal was to improve the agricultural production, yield growth and resistance of plants and animals, had been carried 
out much earlier. Some scientists, such as Justus von Liebig (1803-1873) and Nikolai Ivanovich Vavilov (1887-1943) contributed to the improvement in agricultural technology a lot before the idea of Green Revolution was even born, although their research had the same goal: provide food security in the world.

American agronomist and 1970 Nobel Peace Prize laureate, Norman Ernest Borlaug (19142009), is considered to be the inventor of the Green Revolution. However, an invaluable contribution to the implementation of new technologies and improvement of agricultural production, especially in India, was made by a famous geneticist Monkombu Sambasivan Swaminathan. Owing to the enthusiasm of this scientist, the Green Revolution enabled the increase in the production of wheat in India from 12 million tons in 1965 to over 20 million tons annually during the 1970s. By applying achievements of the Green Revolution, in 1974, India produced sufficient quantities of wheat to meet the needs of its population (Fresco, 2015).

In the past half century, the Green Revolution had an important role in the improvement of agriculture production and provision of food security in the world. Wheat, rice and corn yield in developing countries have increased by 100 to $200 \%$ from the 1960 until today (Davis et al., 2002). The increase in yield was a primary mission of the Green Revolution. The selection and creation of new varieties also meant more intensified application of mineral fertilizers, pesticides and irrigation. Goals of the Green Revolution were achieved with a great support of advisory systems, as well as national and international companies which contributed to the transfer of new technologies from scientific and research centres to practice.

However, during the 1980s, after the initial euphoria about the significant increase in yield faded, a considerable disappointment over the Green Revolution surged through West Europe and North America. The book "Silent Spring" by American zoologist and biologist, Rachel Carson (1907-1964), which describes in detail adverse effects of DDT and similar pesticides on people's health and the environment, is just one of the many accusations brought against the Green Revolution and its achievements. While this book is considered to be one of the key drivers of the modern environmental movement in the West Europe and America, in countries of so-called third world it is seen as the culprit for the spread of malaria and other diseases.

Twenty years after the beginning of the Green Revolution, natural resources and biodiversity were seriously harmed. In addition to a series of positive effects it had in terms of yield growth and production, the Green Revolution considerably contributed to the devastation of the nature, which calls into question the justification of its name. Intensive and often irrational use of modern agro-technical measures led to the reduction of quality of soil, water and air.

Actual achievements of the Green Revolution are also limited in terms of the range of products, the yield and production of which were increased. Namely, according to achieved results, the Green Revolution has significantly contributed to the increase of yield to only a few basic agricultural products. Other products, especially the ones which constitute the basis of nutrition in poor areas of Sub-Saharan Africa were excluded from the Green Revolution effects. 
From the social and economic aspect, the Green Revolution did not have sufficiently balanced solutions. Focused exclusively on the farmers who can provide inputs and modern agro-technical measures, the Green Revolution bypassed small farm households which not only have insufficient financial resources but also do not have access to loans. The fact that, despite the Green Revolution, the number of the poor and hungry is still unacceptably high, supports the fact that achievements of biotechnology development have not been accessible to most of the world population. The most significant reasons of slow introduction of modern technologies to poor farmers are:

- unequal distribution of farming land and unregulated land ownership rights,

- poor or difficult access to loans and other sources of financing;

- no market access,

- discrimination of small households through subsidies which favor large holdings,

- discrimination of women in terms of their inability to become owners of land and farm households,

- lack of agricultural advisory services, etc. (Marković, 2011).

Unintended consequences which occurred as a result of irrational use of water, degradation of land and overuse of chemicals which occurred as a result of application of agrotechnical measures applied within Green Revolution, have not contaminated only the area with agricultural production, but also surrounding land, thus jeopardizing ecosystem and biodiversity. A slowdown in dynamic growth of yield during the 1980s could be partly ascribed to the need for reducing environmental degradation, primarily limited land resources. Even then, negative impacts on cropland areas were recognized as an important drawback of long-term application and sustainability of Green Revolution.

The negative effect of the Green Revolution on the environment should not be seen only as a consequence of application of intensification production concept and agro-technical measures which include agricultural machinery and agrochemicals. In many cases, the agrarian policy of developing countries, was promoting the excessive use of agrochemicals together with the Green Revolution. That was accomplished by applying protective prices of finished products, as well as the system of subsidies for the purchase of: fertilizers, pesticides, irrigation system etc. In cases where the agrarian policy was based on sustainable development, producers followed that example by limiting the excessive use of pesticides. The best example is Indonesia where the Government removed subsidies for the purchase of agrochemicals at the beginning of 1990s. As a result, the application of insecticides which were jeopardizing the ecosystem reduced significantly (Pingali, 2012).

One of the achievements of biotechnology, genetic engineering and its product, genetically modified food, was marked by great controversy. Abuses and the fight for profit of some multinational companies have created the environment in which genetic engineering has a negative connotation. Neglecting positive effects achieved by the implementation of genetic engineering in food production, public opinion created mostly negative attitude towards the research carried out in this field of biotechnology. 
It can often be heard, not only by general public and non-governmental organizations, but by government officials as well, that genetically modified food is a priori considered negative and harmful for human health (Fresco, 2015). Moreover, benefits of these technologies as compared to their potential drawbacks are almost never precisely defined. Due to the growing gap between agricultural science and public opinion, it is necessary to develop a bridge which will enable further development of science with a full support of the society.

The change in the attitude of the society towards biotechnology should take a direction in which, through active participation and contribution of all relevant subjects, the importance of science and knowledge should be confirmed, both through the survival and food security provided for present generations and the prosperity of future generations. Moreover, an important aspect, which should not be neglected in the development of agriculture, is the conservation of natural resources and biodiversity. The sustainability of agricultural development, achieved by rational exploitation of natural resources together with meeting growing food demand of the world population, represents the basis of the sustainable intensification concept, whose application has already started in some regions of the world.

\section{The concept of sustainable intensification in agriculture}

According to the FAO data, in Sub-Saharan Africa, 230 million people and $40 \%$ of children under the age of five are physically and mentally stunted as a result of malnutrition (FAO, 2015). The agreement reached in September 2015 between 193 countries was defined as a new sustainable development global goal and it means wiping out hunger by 2030 . The four key challenges which need to be addressed in order to fulfill this goal are:

- $\quad$ food market integration on regional, national and global level,

- intensification of agricultural production to the extent which does not jeopardize the environment,

- development of science in the field of agriculture and agricultural advisory, and

- $\quad$ economic empowerment of small family farms (Kharas et al., 2015).

Therefore, in order to win the fight against hunger, malnutrition and poverty, and at the same time to preserve and improve environment, it is necessary to globally promote the concept of sustainable intensification of agriculture. The sustainable intensification of agricultural production is a concept which, in the long run, means that by applying innovations and with rational approach to inputs more food will be produced and adverse impacts on the environment will be reduced (Jumma et al., 2013). The sustainable intensification is nothing more than a pursuit for the way to increase production with minimal environmental impacts. In accordance with the key idea of this concept, it is frequently described as a sustainable increase of yield or ecological intensification (Godfray, Garnett, 2014). The concept of sustainable intensification in agriculture could present a function of profit maximization with minimal losses despite its four limitations: (1) the need for the increase in yield, (2) limitation of resources, (3) the need for environmental protection and (4) the issue of food insecurity. 
This approach to the agricultural development is primarily focused on the preservation of natural resources and maintenance of balance. However, it has other dimensions as well. Five questions which are directly related to the application of the concept of sustainable intensification of agriculture are as follow:

- the welfare of farm animals;

- food consumption;

- rural economy, and

- $\quad$ sustainable development.

Conservation of biodiversity and the use of land. By engaging land and water resources, agricultural production threatens biodiversity. In that sense, agriculture presents more serious threat to biodiversity than any other human activity. One of the ways to reduce the negative effect of agriculture is its integration with activities related to environmental protection through practice, the so-called land sharing. In order to maintain production on a reasonable level, when lower yield is caused by sustainable agriculture, the engagement of more farmland is required. In such conditions, the concept of sustainable intensification suggests an alternative solution, that is, sharing of land between agriculture production and conservation. Consequently, the food production growth is enabled on cultivated farmland, while, at the same time, a part of the land on the other location is left for the needs of so called, conservation.

Animal welfare. The word "intensification" and animal welfare can hardly be used together. Namely, it has been proved that intensive conventional production has extremely negative effect on the health and welfare of animals. The successful application of sustainable intensification concept in livestock production means:

- establishing ethical framework which would, in the context of animal welfare, abolish some breeding options,

- identifying areas with greatest potential for the implementation of the sustainable intensification concept, achieving, at the same time, satisfactory results related to animal growth and development, and

- recognizing limitations to respond to future growing demand for livestock products, having in mind animal welfare. It is also a signal which indicates the need to carry out urgent activities in order to reduce overconsumption and souring demand in certain countries.

Human nutrition. In addition to adequate energetic values and protein content, food security also refers to meeting the needs of the population for various microelements through food intake. The key determinant to the quality of human nutrition is variety. The development of agricultural technology has so far been, to a great extent, focused on the yield increase and not on the improvement of quality and variety of agricultural-food products. The key principle of the sustainable intensification concept is, in addition to yield increase, to take care of the 
quality and variety of food in agriculture.

Rural economy. In many countries, the agricultural policy is inextricably linked with the economic support to the rural economy development. The key and measures of support could be radically improved through the application of sustainable intensification concept. Therefore, it is necessary to:

- $\quad$ identify the areas in which existing mechanisms of support could be reoriented to encourage the implementation of sustainable intensification concept,

- $\quad$ innovate the work of agricultural advisory services in order to provide support in the implementation of the new concept of sustainable agricultural intensification, and

- $\quad$ encourage the use of modern information and communication technologies and appropriate financial instruments which would enable the rural population to apply the sustainable intensification concept according to market demands.

Sustainable development. The increase in yield and income are priorities for low income farmers in newly developed countries. Achieving these priorities is, however, often impossible due to limitations related to economic, physical and human capital as well as institutional drawbacks. As a result of stated priority goals and numerous limitations which stand in the way of their achievement, it is very important to assess the ability of this group of countries to direct their agricultural investments to production technologies which will enable sustainable development in the long-run. Therefore, it is necessary to introduce sustainable agricultural intensification, as a new approach to food production, in all strategies and sustainable development plans. In order to achieve this, it is necessary:

- for the society and creators of agricultural and rural policy to recognize the sustainable intensification concept as an approach which may influence positively on the strengthening of rural communities, improvement of small family households and employment, avoiding at the same time negative social and cultural impacts, such as loss of fertile agricultural land and migrations of rural population,

- $\quad$ to invest in social, financial, natural and physical capital in order to provide successful implementation of sustainable intensification concept, and

- $\quad$ in cases where sustainable development goals (such as preventing migrations or biodiversity conservation) demand highly expensive activities, it is necessary to develop mechanisms which will provide appropriate measures to economically weak producers through a system of subsidies.

The success of implementation of sustainable intensification concept in terms of reduction of poverty and hunger, that is, provision of food security, depends on a number of factors. International and national research centres in the field of agriculture present subjects whose activities greatly determine the success of sustainable intensification concept. In addition, all other relevant participants in the food chain, from producers and consumers to nongovernment organizations and universities, give valuable contributions to ending poverty in rural areas. Also, the success of sustainable intensification is determined by choosing 
an appropriate approach to agricultural development. There are three key approaches: agroecological, genetic and social-economic. Agroecological approach means the implementation of ecological principles in agricultural practice. Genetic approach is the application of modern achievements of molecular biology. Social-economic approach means the use of social, economic and institutional measures. Each of the three principles makes its own specific contribution, in terms of sustainable development, biodiversity conservation or reduction of greenhouse gas emissions. Although the benefits of these three approaches vary, their combination can lead to minimizing adverse effects and maximizing environmental and economic benefits.

Social-economic approach of sustainable intensification is often unjustly neglected. Its importance is crucial for the successful application of the concept of sustainable agricultural intensification. Social, economic and institutional measures provide favourable setting for successful implementation of innovations. The development of efficient market, of both input and finished products, proved to be an important condition for successful intensification. This primarily refers to an unhindered access of farmers to the market of seed and plant material, fertilizers and other inputs, loans, funds and other financial resources, warehouses as well as high quality consulting services. The development of stable and long term agricultural policy provides necessary security to agricultural producers. Moreover, the key idea behind the implementation of the sustainable intensification concept is not imposing a certain system or production technology by agricultural and rural development policy developers, but letting farmers choose optimal technology according to the region in which they produce (Pretty, 1997).

Table 1. Aspects and accesses to the concept of sustainable agricultural intensification

\begin{tabular}{|l|ll|}
\hline \multirow{4}{*}{ Multiple benefits } & - & Rational use of inputs \\
& - & Reducing degradation of land \\
& - & Reducing greenhouse gas emission \\
& - & Strengthening the so-called natural capital \\
\hline \multirow{3}{*}{$\begin{array}{l}\text { Involving more } \\
\text { subjects }\end{array}$} & - & Agricultural producers \\
& - & Consumers \\
& - & Crivate sector \\
\hline Implementing & - & International and national research centres \\
various approaches & - & Universities \\
\hline Working on more & - & Ecological intensification \\
levels & - & Social and economic intensification \\
\hline
\end{tabular}

Source: Jumma et al., 2013. 
Given numerous uncertainties and open questions accompanying the concept of sustainable agricultural intensification, the implementation of this concept has stirred up much controversy. One of the greatest challenges is gaining public acceptance. However, despite some resistance to sustainable intensification, it has been widely accepted that the most important priority, on the global level, is the production of sufficient amount of food while preserving the socalled natural capital (UN, 2014). Prevention of further land and water degradation, together with the prevention of climate changes which are accepted worldwide, are another proof that innovations in agricultural practices are inevitable in the near future.

\section{Conclusion}

In the past few decades, advancements in the field of biotechnology in synergy with other relevant facts, has led to some improvements regarding the world food situation. According to the official data, however, rural poverty and hunger on a global level is still unacceptably high. The reduction of population who live in extreme poverty imposes the need for the food production increase. Furthermore, the expansion of agricultural production in future is conditioned by projected growth of the world population, which, by rule, is most rapid in the food-wise most vulnerable regions. Due to the fact that the pressure on the environment caused by agriculture is rapidly increasing, the issue of global food security should not be treated as one-dimensional. Consequently, the idea of new agricultural production concept developed. It lies between conventional and organic agriculture and its aim is to conserve natural resources and biodiversity.

A sustainable intensification, as a concept of agricultural development and an element of achieving food security is still categorized as an innovation. Similarly to other innovations, sustainable intensification concept has to accept some compromises. Advantages which are expected and the ones which should be achieved in the short term are frequently off balance. Bringing these two poles closer together, calls for a higher degree of flexibility, that is, adapting to specific conditions of regions and countries when applying sustainable intensification concept. A holistic approach, which means the combination of conservation agriculture and cultivation of high yielding varieties, while applying the principle of integrated pesticide management, should minimize adverse environmental impacts of agriculture, maximizing at the same time positive effects.

Speaking of sustainable intensification concept in terms of a new agricultural development concept, it is important to point out that there are still more open questions than responses. In order for the concept of sustainable agricultural intensification to improve the world food state, it should be recognized as an opportunity and accepted by: scientific and research organizations and institutions, markets, and educational and advisory systems. Food security and responses to challenges regarding the conservation of limited natural resources, primarily the soil, depend on the pace of the development of new technologies. Agricultural and rural policies in developing countries should primarily enable establishing of institutions and creating "favourable climates" in which an innovation, such as sustainable agricultural intensification, will be adopted. 
Despite being a new concept whose goals are already subject of numerous discussions and debates, sustainable intensification should not be observed as a single step, but as one of the important steps which should be carried out in order to improve the so-called food system and provide sustainable development and food security on the global level.

It is necessary to create room for such innovative approach to modern agriculture since "the science of the past will not meet demands of the future." (Bertini, Glickman, 2013).

\section{References}

1. Bertini, C., Glicman, D. (2013): Advancing global food security. The power of science, trade and business, available at: www.thechicagocouncil.org/UserFiles/File/ GlobalAgDevelopment/2013 SymposiumGlobal Food Securityembargoed.pdf

2. Bindraban, P.S., van der Velde, M., Ye, L., van der Berg, M., Materechera, S., Kiba, D.I., Hoogmoed, W. (2012): Assessing the impact of soil degradation on food production, Current Opinion in Environmental Sustainability, Vol. 4, No. 5, pp. 478-488

3. Đurić, K. (2015): Food security as a goal of global sustainable development after 2015, Contemporary Agriculture, Vol. 64, No. 3-4, pp. 255-261

4. FAO (2001): Conservation agriculture. Case studies in Latin America and Africa, available at: www.fao.org/docrep/003/y1730e/y1730e03.htm

5. $\quad$ FAO (2011): Land degradation assessment in drylands (LADA), Project findings and recommendations, Unated Nations environmental programme, FAO, Rome

6. FAO (2015): The State of Food Insecurity in the World, Meeting the 2015 international hunger targets: taking stock of uneven progress, Rome

7. Fresco, L.O. (2015): The new green revolution: bridging the gap between science and society, Current Science, Vol. 109, No. 3, pp. 430-438

8. Goldfray, H.C.J., Garnett, T. (2014): Food security and sustainable intensification, Phil. Trans. R. B 369: 20120273. http://dx.doi.org/10.1098/rstb.2012.0273

9. Harvey, M., Pilgrim, S. (2011): The new competition for land: Food, energy, and climate change, Food Policy, No. 36, pp. 40-51

10. Juma, C., Tabo, R., Wilson, K., Conway, G. (2013): Innovation for Sustainable Intensification in Africa, The Montpellier Panel, Agriculture for Impact, London

11. Kharas, H., McArthur, J., Gertz, G., Nowlds, S., Noe, L. (2015): Ending rural hunger: mapping needs and action for food and nutrition security, Global Economy and Development at Brookings, http://endingruralhunger.org

12. Marković, K. (2011): Development factors of agriculture and their influence upon the world food situation, Agroekonomika, No. 51-52, pp. 49-58

13. Montanarella, L. (2007): Trends in land degradation in Europe, In Climate and Land Degradation, Edited by Sivakumar MVK, Ndiang N. Berlin/Heidelberg: Springer, pp. 83104

14. Pejanović, R. (2015): Neodrživost dosadašnjeg koncepta razvoja i problem 
prehrambene bezbednosti hrane, Letopis naučnih radova, Vol. 39, No. 1, pp. 141-152, Poljoprivredni fakultet, Novi Sad

15. Petit, S., Munier-Jolanin, N., Bretagnolle, V., Bocktaller, C., Gaba, S., Cordeau, S., Lechenet, M., Meziere, D., Colbach, N. (2015): Ecological Intensification Through Pesticide Reduction: Weed Control, Weed Biodiversity and Sustainability of Arable Farming, Environmental Management, Vol. 56, pp. 1078-1090

16. Phalan, B., Balmford, A., Green, R., Scharlemann, J. (2011): Minimising the harm to biodiversity of producing more food globally, Food Policy, Vol. 36, pp. 62-71

17. Pingali, P.L. (2012): Green Revolution: Impact, limits, and the path ahead, PNASProceedings of the National Academy of Science of the United States of America, Vol. 109, No. 31, pp. 12302-12308

18. Pretty, J.N. (1997): The sustainable intesification of agriculture, Natural Resources Forum, Vol. 4, pp. 247-256

19. Pretty, J.N. (2008): Agricultural sustainability: concepts, principles and evidence. Philos. Trans. Roy. Soc. B 363, pp. 447-465

20. Tilman, D. et al. (2009): Beneficial biofuels - the food, energy and environment trilemma. Science 325 (July), pp. 270-271

21. Tilman, D., Balzer, C., Hill, J., Beford, B. (2011): Global food demand and the sustainable intensification of agriluture, PNAS, Vol. 108, No. 50, pp. 20260-20264

22. UNITED NATIONS (2013): World population prospects: the 2012 Revision, available at: https:/www.un.org/development/desa/en/news/population/un-report-worldpopulation-projected-to-reach-9-6-billion-by-2050.html

23. UNITED NATIONS (2014): The road to Dignity by 2030 - Ending poverty, Transforming All Lives and Protecting the Planet, Syntesis Report of the Secretary-General On the Post-2015 Agenda, New York

24. Wright, J. (2008): Sustainable Agriculture and Food Security in an Era of Oil Scarcity. Earthscan. London 


\title{
ODRŽIVA INTENZIFIKACIJA POLJOPRIVREDE KAO FAKTOR OSTVARIVANJA PREHRAMBENE SIGURNOSTI
}

\author{
Katarina Đuric ${ }^{3}$, Zoran Njegovan ${ }^{4}$
}

\begin{abstract}
Rezime
Na vrhu liste prioriteta održivog globalnog razvoja posle 2015. godine, definisanog od strane Ujedinjenih Nacija, nalazi se eliminisanje gladi, ostvarivanje prehrambene sigurnosti $i$ promovisanje održivog razvoja. Dosadašnji napori čovečanstva na planu redukcije ruralnog siromaštva, realizovani kroz Zelenu revoluciju, pored pozitivnih, ostvarili su i niz negativnih efekata, pre svega, na prirodne resurse. Bespovratna devastacija zemljišta, narušavanje kvaliteta vode i vazduha, kao i ugrožavanje biodiverziteta, prepoznati su kao ključni elementi neodrživosti postojećeg razvojnog koncepta poljoprivrede. U skladu sa tim, javlja se potreba za primenom novog koncepta agrarnog razvoja, koji će se suštinski nalaziti između intenzivne konvencionalne i organske poljoprivrede.

Koncept koji se već uveliko primenjuje u pojedinim regionima sveta, a čiji je osnovni cilj da pronađe način da se poveća proizvodnja uz istovremeno što manje negativne uticaje na životnu sredinu je održiva intenzifikacija poljoprivrede. Cilj ovog rada je da sagleda sve, kako pozitivne, tako i negativne aspekte dosadašnjeg razvoja biotehnologije i ukaže na mesto i ulogu koju bi koncept održive intenzifikacije trebalo da ima u očuvanju prirodnih resursa $i$ ostvarivanju prehrambene sigurnosti.
\end{abstract}

Ključne reči: prehrambena sigurnost, biodivezitet, zemljište, zelena revolucija, održiva intenzifikacija

3 Docent, dr Katarina Đurić, Univerzitet u Novom Sadu, Poljoprivredni fakultet, Trg Dositeja Obradovića br. 8, 21000 Novi Sad, Srbija, Telefon: +381 214852 232, E-mail: katarina.djuric@polj.uns.ac.rs

4 Redovni professor, dr Zoran Njegovan, Univerzitet u Novom Sadu, Poljoprivredni fakultet, Trg Dositeja Obradovića br. 8, 21000 Novi Sad, Srbija, Telefon: +381 214853 393, E-mail: njegovan@polj.uns.ac.rs 